Article

\title{
Antioxidant and Cytoprotective Effect of Piper aduncum L. against Sodium Fluoride (NaF)-Induced Toxicity in Albino Mice
}

\author{
Oscar Herrera-Calderon ${ }^{1, *}$, Luz Chacaltana-Ramos ${ }^{2}$, Ricardo Ángel Yuli-Posadas ${ }^{3}$, \\ Bertha Pari-Olarte ${ }^{2}$, Edwin Enciso-Roca ${ }^{4}$, Johnny Aldo Tinco-Jayo ${ }^{4}$, Juan Pedro Rojas-Armas ${ }^{5}$ (D), \\ Luis Miguel Visitación Felix-Veliz ${ }^{1}$ and Cesar Franco-Quino ${ }^{6}$ \\ 1 Faculty of Pharmacy and Biochemistry, Universidad Nacional Mayor de San Marcos, Lima 15001, Peru; \\ lfelixv@unmsm.edu.pe \\ 2 Faculty of Pharmacy and Biochemistry, Universidad Nacional San Luis Gonzaga, Ica 11001, Peru; \\ luzjos934@gmail.com (L.C.-R.); berthapari@hotmail.com (B.P.-O.) \\ 3 Universidad Continental, Huancayo 12002, Peru; ryuli@continental.edu.pe \\ 4 Faculty of Health Sciences, Universidad Nacional de San Cristóbal de Huamanga, Ayacucho 05001, Peru; \\ encisoqf@hotmail.com (E.E.-R.); aldotinco2@hotmail.com (J.A.T.-J.) \\ 5 Faculty of Medicine, Universidad Nacional Mayor de San Marcos, Lima 15001, Peru; \\ jprojasarmas@yahoo.com \\ 6 Faculty of Dentistry, Universidad Nacional Mayor de San Marcos, Lima 15001, Peru; \\ cesar.franco1@unmsm.edu.pe \\ * Correspondence: oherreraca@unmsm.edu.pe; Tel.: +51-956-550-510
}

Received: 7 April 2019; Accepted: 6 May 2019; Published: 16 May 2019

\begin{abstract}
Piper aduncum, commonly known as matico, is a plant that grows in the mountainous and coastal regions of Peru, and is studied for its antimicrobial properties and various ethnopharmacological uses. The main objective of this study was to determine the cytoprotective and antioxidant effects of the methanolic extract of Piper aduncum leaves in Mus musculus previously administered with sodium fluoride $(\mathrm{NaF})$ using the Micronucleus test and the Comet assay. The extract was administrated orally in four different concentrations: 150, 300, 600, and $1200 \mathrm{mg} / \mathrm{Kg}$ for ten days. At the 11th day, a single dose of $\mathrm{NaF}$ was administrated via intraperitoneal at $20 \mathrm{mg} / \mathrm{Kg}$. The genotoxicity study was performed with mice from the strain $\mathrm{BALB} / \mathrm{c}$, using the Micronucleus test on bone marrow and the Comet assay on peripheral blood according to OECD guidelines 474 and 489 , respectively. The statistical analysis was performed by median analysis with ANOVA. Significant differences were found in Micronucleus frequency between the highest concentrations of Piper aduncum and $\mathrm{NaF}$. The Comet assay showed significant reduction of NaF-induced damage on erythrocytes depending on the different concentrations of the extract which were evaluated in this study. It is concluded that the methanolic extract of $P$. aduncum leaves has cytoprotective and antioxidant activity against sodium fluoride.
\end{abstract}

Keywords: Piper aduncum; antioxidant; cytoprotective; micronucleus test; Comet assay

\section{Introduction}

Piper aduncum L. (P. aduncum) is known as "matico", in different places from Peru and widely used in the traditional medicine of Latin-America. The Piperaceae family, in which the genus Piper belongs, comprises approximately 2000 species distributed in the tropical regions worldwide [1]. P. aduncum is used in folk medicine as an anti-inflammatory, for wound healing, treating rheumatic afflictions and diarrhea, and as an antiseptic. [2] Previous phytochemical studies of P. aduncum reported the 
isolation of chalcones, dihydrochalcones, flavanones, chromene, phenylpropanoids, and benzoic acid derivatives. Some of them are shown in Figure 1, which have been studied as cytotoxic, antimicrobial, and insect repellent agents [3,4].<smiles>COC(=O)c1cc(O)c2c(c1)C=CC(C)(C)O2</smiles>

methyl-8-hydroxy-2,2-dimethyl-2Hchromene-6-carboxylate<smiles>CC(C)=CCc1cc(C(=O)O)cc2c1OC(C)(C)C=C2</smiles>

2,2-dimethyl-8-(3-methyl-2-butenyl) -2H-chromene-6-carboxylic-acid<smiles>C=C(C)C(O)CC/C(C)=C/Cc1cc(C(=O)OC)ccc1OC</smiles>

methyl-3-(6-hydroxy-3,7-dimethyl-2, 7-octadienyl)-4-methoxybenzoate<smiles>COc1cc(O)c(C(=O)CCc2ccccc2)c(O)c1</smiles><smiles>O=C1C[C@@H](c2ccccc2)Oc2cc(O)cc(O)c21</smiles>

2',6'-dihydroxy-4'-methoxydihydrochalcone

Aduncumene<smiles>COC(=O)c1ccc(O)c(C(C=C(C)C)c2c(OC)cc(O)c(C(=O)CCc3ccccc3)c2O)c1</smiles>

Piperaduncin-C<smiles>COC(=O)c1ccc(O)c(C2c3c(OC)cc(O)c(C(=O)CCc4ccccc4)c3O[C@H]2C(C)(C)O)c1</smiles>

Piperaduncin-B

Figure 1. Main phytochemicals found in Piper aduncum L. leaves.

Pharmacological effects of P. aduncum extracts (ethanol and methanol) and its essential oil have been demonstrated, including antileishmanial, antibacterial, cytotoxic, and antifungal activities [5]. Furthermore, isolated compounds from leaves have been shown to be very active against promastigote and intracellular amastigotes, causing damaging effects on DNA, and have antileishmanial, antimicrobial, molluscicidal, antitumor, and antifungal activities [6,7]. Otherwise, it has been demonstrated that some species of Piper have antitumor activity, such as Piper claussenianum, which has an in vitro effect on breast cancer tumor cell lines (MCF-7). P. longum and P. nigrum have been 
evaluated as immunomodulatory, antioxidant, and antiproliferative agents in breast cancer in vitro [8]. Other studies tested the essential oil of $P$. aduncum leaves and have evidenced its variety of uses as a molluscicide, insecticide, and antibacterial agent [9].

Sodium fluoride $(\mathrm{NaF})$ is an inorganic salt used commonly on dental treatments to prevent caries, topically, or in some cases in municipal water fluoridation systems. It has also been used as an insecticide, wood preservative, and in the manufacture of glass. It has also been used in cytotoxic research models. In high doses it has a very potent oxidative effect which causes direct damage to DNA molecules. For example, it can break DNA strands and cause apoptosis in human cells, such as erythrocytes, and generate oxidative stress on oral mucosa from rats. Among the main adverse reactions is the generation of free oxygen radicals in cells [10]. Studying genotoxicity can done via biological models such as the Micronucleus (MN) test and the Comet assay. The mammalian in vivo MN test's purpose is to identify substances that cause cytogenetic damage, which results in the formation of micronuclei on the studied cells, in this case the erythrocytes [11]. The chosen cells are studied in the bone marrow, because their maturing progress consists of expulsing the nucleus; therefore, any damage to the DNA can be seen in this process, especially because the mature kind lacks a nucleus. The in vivo alkaline Comet assay is used to detect DNA strand breaks in cells under alkaline conditions ( $\mathrm{pH}>13$ ); these breaks can be the result of direct interactions with DNA, sites of DNA that are alkali labile, or as a consequence of transient DNA strand breaks resulting from DNA excision repair [12].

Peruvian flora is considered one of the best sources of curative plants in the world [13] Furthermore, various species with potential use for commercial purposes have not been studied, and until today there previous study on the cytoprotective effect of $P$. aduncum from Peru. Environmental conditions can alter phytochemical production, thus plants from different regions may have different profiles.

Although, a wide number of phytocompounds (including alkaloids, phenolic compounds, glycosides, flavonoids, anthocyanins, etc.) may have cytotoxic and genotoxic properties, the phytochemicals of Piper species, in addition to having a long history of use, their natural origin and widespread use do not guarantee their safety. Therefore, the aim of this study was to determine the cytoprotective and antioxidant effects of the methanolic extract of P. aduncum leaves in albino mice previously administered with sodium fluoride $(\mathrm{NaF})$ using the Micronucleus test and the Comet assay.

\section{Materials and Methods}

\subsection{Chemicals}

The materials applied in this research are as follows: 2-thiobarbituric acid (TBA), gallic acid, quercetin, $\mathrm{FeCl}_{3}, \mathrm{MgCl}_{2}$, Triton X-100, $\mathrm{NaCl}$, Tris, EDTA, Boric acid, and DMSO from Merck; Folin-Ciocalteu reagent (FCR), 2,4,6-tripyridyl-striazine (TPTZ), 2,2'-azino-bis-3-ethylbenzthiazoline-6-sulphonic acid (ABTS) and 1,1-diphenyl-2-picrylhydrazyl $(\mathrm{DPPH})$ radical and all chemicals used in our study were of analytical or reagent grade (Sigma-Aldrich, St. Louis, MO, USA).

\subsection{Plant Material}

The leaves of P. aduncum were collected from Huamanga, Ayacucho, Peru in January 2018 and taxonomically identified by the staff at the Herbarium from Universidad Nacional Mayor de San Marcos (Lima, Peru).

\subsection{Experimentation Animals}

For the acute oral toxicity experiment: six male Hotzman albino rats weighing 180-190 g (6-8 weeks old) were divided in two groups, one being the control. For feeding, balanced rodent special food was 
used and animals had access to water ad libitum. Physical conditions were: temperature at $19.6{ }^{\circ} \mathrm{C}$, humidity $67 \%$, and $12 \mathrm{~h}$ light/dark natural cycle.

For the micronucleus test and comet assay: 30 healthy, albino mice Mus musculus (BALB/c) between 6-10 weeks olds, weighing 25-35 g were supplied by the Instituto Nacional de Salud (Lima) seven days before the experiments. Animals were brought to the animal facilities of the university and kept in boxes in air-conditioned room $\left(23^{\circ} \mathrm{C}\right)$ and relative humidity of $50 \%$, with a 12 -h dark/light cycle and were fed with special balanced pellet (Instituto Nacional de Salud, Peru) and water ad libitum.

All protocols were approved by the Ethics Committee of the Faculty of Medicine, UNMSM, Act 0310 (approval date: 4 November 2017) in accordance with the Guide for the Care and Use of Laboratory Animals.

\subsection{Extract Preparation}

The dried leaves of P. aduncum were ground to powder form. The powder was soaked for $72 \mathrm{~h}$ in an appropriate volume of methanol to obtain $100 \mathrm{mg} / \mathrm{mL}$ solution. The solution was evaporated by using a rotavap in order to obtain a dried extract, then it was stored in a brown vial at $4{ }^{\circ} \mathrm{C}$ until further use [14].

\subsection{Antioxidant Activity}

To determine the antioxidant capacity, three tests were performed:

\subsubsection{Ferric Reducing ability of plasma (FRAP)}

FRAP assays were performed using the technique by Benzie and Strain (1996) modified by Rao et al. [15]. One $\mathrm{mL}$ of the FRAP substance was mixed with $1 \mathrm{~mL}$ distillated water and the extract of Piper aduncum, then exposed at $37^{\circ} \mathrm{C}$ for 15 minutes and read on the spectrophotometer $(539 \mathrm{~nm})$ compared with a standard curve with different concentrations of $\mathrm{Fe}^{+2}$.

\subsubsection{2-Diphenil-1-picrilhidracil (DPPH)}

The technique used was proposed by Brand-Williams et al. (1995) [16]. The assay mixture consisted of various concentrations of extract at $1 \mathrm{~mL}$ of acetate buffer $\mathrm{pH} 6(0.1 \mathrm{M})$, methanol, and $0.5 \mathrm{~mL}$ of DPPH $0.1 \mathrm{mM}$, mixed and heated at $37^{\circ} \mathrm{C}$ for $30 \mathrm{~min}$ to be read on spectrophotometer at $517 \mathrm{~nm}$. The control was made comparing with the solution of DPPH without the extract.

\subsubsection{Thiobarbituric Acid Reactive Substances (TBARS)}

TBARS assays were performed according the technique described by Draper (1990) [17] which evaluates the lipoperoxidation by measuring the formation of malondialdehyde (MDA) using the reactive acid thiobarbituric in the presence of acid trichloroacetic, then it was read with a spectrophotometer at $532 \mathrm{~nm}$.

\subsection{Determination of Flavonoids and Polyphenols}

According to the technique by Wolfe et al (2003) [18] for flavonoids determination, $205 \mu \mathrm{L}$ of methanolic extract was mixed with $125 \mu \mathrm{L}$ water and $75 \mu \mathrm{L}$ sodium nitrate at $5 \%$. It was set for 5 min and then aluminum trichloride was added at $10 \%$. The mixture was set again for 6 min and $0.5 \mathrm{~mL} 2 \mathrm{M}$ sodium hydroxide and $275 \mu \mathrm{L}$ water were added, then the mixture was measured by spectrophotometer at $510 \mathrm{~nm}$. The technique for polyphenols determination was from Herrera et al. [1]. For the mixture, $1 \mathrm{~mL}$ of Folin-Ciocalteu solution at $10 \%$ and $0.1 \mathrm{~mL}$ of the extract were set for $5 \mathrm{~min}$, then added $1 \mathrm{~mL}$ of sodium carbonate at $7.5 \%$. After 15 minutes, it was read by spectrophotometer at $725 \mathrm{~nm}$. 


\subsection{Acute Oral Toxicity}

According to OECD guideline 423 for testing chemicals [19], the animals were treated and observed for 14 days. The treated group (three rats) were fed with the extract at a concentration of $2000 \mathrm{mg} / \mathrm{Kg} /$ day using an intragastric cannula and the control group (three rats) with $1 \mathrm{~mL}$ distillated water. The animals were weighed at the beginning of the experiment, at the 7th day, and at the end. Then, they were sacrificed by cervical dislocation for macroscopic organ analysis. During the entire experiment (14 days), abnormal behavior was recorded.

\subsection{Genotoxicity Study}

Following OECD guidelines 474 for MN and 489 for Comet assay [20], the treatment lasted ten days, and the 30 animals were divided into six groups of five mice each (three males and two females): the negative control group was administrated orally with the diluent, DMSO 10\%, and no bioactive substances; the extract was administrated through an intragastric cannula at different doses of $150 \mathrm{mg} / \mathrm{Kg}$, $300 \mathrm{mg} / \mathrm{Kg}$, $600 \mathrm{mg} / \mathrm{Kg}$, and $1200 \mathrm{mg} / \mathrm{Kg}$; the positive control group did not receive any substance until day 11, when all groups except the negative control were administrated with a single dose of $20 \mathrm{mg} / \mathrm{Kg} \mathrm{NaF}$ via intraperitoneal injection. The animals were observed for one more day until day 12 , when they were sacrificed by cervical dislocation.

\subsubsection{Micronucleus Test}

After the sacrifice, the femur was removed for the extraction of bone marrow with physiological serum enriched with BSA $10 \%$ and centrifuged at $1500 \mathrm{rpm}$, the supernatant was disposed, and the cellular sample was smeared and left to be dried and fixed with cold methanol. The slides were stained with Giemsa $2 \%$ for the microscopic analysis at 1000× using a Nikon Eclipse 50i microscope. OECD guideline 474 establishes the identification of MN cells: a principal nucleus and one or more nuclear structures named MN, the MN is rounded or almond shaped and is $1 / 3-1 / 16$ from the main nucleus, it has the same intensity, texture, and focal plane as the nucleus. Two-thousand polychromatic erythrocytes (1000 cells per replicate) were scored for each sample.

In addition, 500 cells (polychromatic and normochromic erythrocytes) were scored to determinate the cytotoxic index (CTI). This index is used to evaluate the number of cells with DNA damage in comparison with the ones that did not present DNA alterations and could mature, under the premise that genotoxic substances alter the polychromatic erythrocytes.

$$
\text { Cytotoxic index }(\mathrm{CTI})=\frac{\text { polychromatic erythrocyte }}{\text { normochromic erythrocyte }}
$$

\subsubsection{Comet Assay}

The comet assay was performed using the Guidelines of OECD Test 489 Alkaline Comet assay with minor modifications. Approximately $40 \mu \mathrm{L}$ of blood was resuspended in $110 \mu \mathrm{L}$ of $0.5 \%$ low melting point agarose (LMA), smeared on microscope slides precoated with $100 \mu \mathrm{L}$ of $0.5 \%$ normal melting point agarose (NMA) previously dried at $65{ }^{\circ} \mathrm{C}$ and covered with a coverslip and kept at $4{ }^{\circ} \mathrm{C}$ until solidification. The coverslips were removed and cells were lysed for $2 \mathrm{~h}$ at $4{ }^{\circ} \mathrm{C}$ in a dark chamber containing a cold fresh lysing solution. To allow DNA denaturation, unwinding, and exposure of alkali-labile sites, the slides were placed in a horizontal gel electrophoresis tank filled with cold electrophoresis solution for $20 \mathrm{~min}$. Electrophoresis was performed in the same solution for $20 \mathrm{~min}$ at $0.73 \mathrm{~V} / \mathrm{cm}$ and $300 \mathrm{~mA}$. Then, the slides were neutralized with washes for 2-5 min with $0.4 \mathrm{M}$ Tris ( $\mathrm{pH}$ 7.5), fixed with cold absolute ethanol for three min and stored in the dark at room temperature. Before the microscope analysis, the slides were stained with $50 \mu \mathrm{L}$ of Hoescht $33258(50 \mathrm{ug} / \mathrm{mL})$, then observed at 400× magnification at a Nikon Eclipse 50i fluorescence microscope. One hundred randomly selected cells (50 cells from each of the two replicate slides) were analyzed per sample. These cells were visually analyzed according to classes, ranging from undamaged, score 0 (completely 
undamaged; $0 \times 100$ cells) to highly damage, score 400 (completely damaged; $4 \times 100$ cells). On the other hand, to visualize DNA damage, slides were examined at $400 \times$ and 100 cells were randomly selected for analysis in each sample. The tail DNA (\%) and tail moment were used to measure DNA damage because they give the most meaningful results in genotoxicity studies [21].

\subsection{Statistical Analysis}

For the antioxidant activity, the tests results were presented as medians from three determinations \pm standard deviation (SD). The differences between medians were determined by Kruskall-Wallis test. The correlations between variables were made by the Pearson test and performed using SPSS.

For the genotoxicity study, statistical analysis of medians of the different groups of the experiment was made using ANOVA within SPSS. The statistical significance level was 95\%, $p<0.05$.

The percentage reduction reflected the reduction of damage in comparison with the positive and negative control, showing more objectively the cytoprotective effect of the plant extract.

$$
\text { Reduction }(\%)=\left[\frac{A-B}{A-C}\right] \times 100
$$

A: the median of damage in positive control; B: the median of damage in the treatment group (Piper aduncum $+\mathrm{CP}$ ); C: the median of damage in the negative control.

\section{Results}

\subsection{Antioxidant Activity}

The results found for the methanolic extract of Piper aduncum leaves are shown in Table 1.

Table 1. Bioactive compounds and antioxidant activity of methanolic extract of Piper aduncum leaves.

\begin{tabular}{|c|c|c|c|c|c|}
\hline $\begin{array}{l}\text { Methanolic } \\
\text { Extract }\end{array}$ & $\begin{array}{l}\text { Polyphenols } \\
\text { (mg GAE/g) }\end{array}$ & Flavonoids (mg CE/g) & FRAP $\left(\mu \mathrm{mol} \mathrm{Fe} e^{+2} / g\right)$ & DPPH ( $\mu \mathrm{mol}$ TEAC/g) & $\begin{array}{c}\text { TBARS ( } \mu \mathrm{g} \\
\text { MDA/g) }\end{array}$ \\
\hline & $19.00 \pm 0.8$ & $4.10 \pm 0.11$ & $40.63 \pm 0.65$ & $0.790 \pm 0.5$ & $260.0 \pm 0.56$ \\
\hline \multirow[t]{2}{*}{$\begin{array}{l}\text { Other reports } \\
\text { of antioxidant } \\
\text { activity }\end{array}$} & $\begin{array}{l}4.94 \pm 0.05 \\
\text { (ethanol } \\
\text { extract) [22] }\end{array}$ & $\begin{array}{c}3.8 \pm 0.03 \text { (n-hexane extract) } \\
6.7 \pm 0.02 \text { (ethyl acetate extract) } \\
8.3 \pm 0.01 \text { (ethanol extract) [22] }\end{array}$ & $\begin{array}{l}121.03 \pm 0.27(\mu \mathrm{g} \\
\quad \text { ascorbic acid } \\
\text { equivalent } / \mathrm{mL})[22]\end{array}$ & $\begin{array}{c}1248.82 \pm 17.14 \mu \mathrm{g} / \mathrm{g} \text { (n-hexane extract) } \\
1454.7 \pm 0.38 \mu \mathrm{g} / \mathrm{g} \text { (ethyl acetate extract) } \\
129.54 \pm 0.41 \mu \mathrm{g} / \mathrm{g} \text { (ethanol extract) }[22]\end{array}$ & \\
\hline & & & & $85.24 \pm 0.60$ (ethanol extract) [23] & \\
\hline
\end{tabular}

GAE—gallic acid equivalents; CE—catechin equivalents; Data represented as means $\pm \mathrm{SD}(n=3)$.

Total polyphenols estimated using the Folin-Ciocalteu method were found in a lower amount (16.09 mg GAE/g). Flavonoid contents were also found to be minor (3.58 mg CE/g). Although, Herrera et al. (2018) [1] reported $311.11 \mathrm{mg} \mathrm{GAE} / \mathrm{g}$ and $154.98 \mathrm{mg}$ RUE (rutine equivalents) for total polyphenols and flavonoid content, respectively, in leaf ethanolic extract from Piper aduncum L. They concluded that their results indicate the position and/or the number of glycosyl groups present in the molecule play a significant part in the antioxidant activity.

\subsection{Acute Oral Toxicity Study}

Oral administration of P. aduncum extract did not produce any mortality or abnormal behavioral response in rats during the 14 days of the experiment. In the anatomopathological study, there were no organ or system alterations compared to the control group. The lethal dose $50\left(\mathrm{LD}_{50}\right)$ for this extract appeared to be $>2000 \mathrm{mg} / \mathrm{kg}$.

\subsection{Genotoxicity Study}

According to the results shown in Table 2, treatments of 150, 300, 600, and $1200 \mathrm{mg} / \mathrm{kg}$ body weight P. aduncum extract caused a significant decrease in the MNPCE frequency by $52.4 \%(9.05 \pm 0.707), 67.9 \%$ (6.42 \pm 1.817$), 83.3 \%(3.81 \pm 0.837)$, and $97.6 \%$ (1.42 \pm 0.894$)$, respectively, compared to NaF exposure $(17.81 \pm 6.140)$, showing the protective capacity of the plant extract. Also, the results of the present 
study showed that the leaf extract of $P$. aduncum can mitigate the cytotoxicity of $\mathrm{NaF}$ and promotes erythropoiesis in mice.

Table 2. Genotoxicity study: Micronucleus test and Comet assay.

\begin{tabular}{|c|c|c|c|c|c|c|c|}
\hline \multirow[b]{2}{*}{ Experimental Group } & \multicolumn{3}{|c|}{ Micronucleus Test } & \multicolumn{4}{|c|}{ Comet Assay } \\
\hline & $\begin{array}{c}\text { MNPCE/1000PCE } \\
(\text { median } \pm \text { SD) }\end{array}$ & $\begin{array}{c}\text { CTI } \\
\text { PCE/NCE }\end{array}$ & $\begin{array}{c}\text { Reduction } \\
(\%)\end{array}$ & $\begin{array}{l}\text { Number of Cells } \\
\text { Expressed as AU }\end{array}$ & $\begin{array}{c}\text { Reduction } \\
(\%)\end{array}$ & $\begin{array}{c}\text { Tail DNA } \\
(\%)\end{array}$ & $\begin{array}{c}\text { Tail } \\
\text { Moment } \\
(\%)\end{array}$ \\
\hline$P A 150 \mathrm{mg} / \mathrm{Kg}+\mathrm{PC}$ & $9.05 \pm 0.707^{a, b}$ & $\begin{array}{c}2.041 \pm \\
0.408\end{array}$ & $52.4 \%$ & $104.23 \pm 10.93^{a, b}$ & $65.58 \%$ & $0.15 \pm 0.01$ & $0.14 \pm 0.01$ \\
\hline$P A 300 \mathrm{mg} / \mathrm{Kg}+\mathrm{PC}$ & $6.42 \pm 1.817^{\mathrm{a}, \mathrm{b}}$ & $3.27 \pm 1.13$ & $67.9 \%$ & $82.40 \pm 22.54^{\mathrm{a}, \mathrm{b}}$ & $75.4 \%$ & $0.17 \pm 0.02$ & $0.11 \pm 0.05$ \\
\hline$P A 600 \mathrm{mg} / \mathrm{Kg}+\mathrm{PC}$ & $3.81 \pm 0.837^{b}$ & $7.96 \pm 2.58$ & $83.3 \%$ & $69.20 \pm 10.56^{b}$ & $82.65 \%$ & $0.25 \pm 0.01$ & $0.16 \pm 0.02$ \\
\hline$P A 1200 \mathrm{mg} / \mathrm{Kg}+\mathrm{PC}$ & $1.42 \pm 0.894^{\mathrm{b}}$ & $\begin{array}{c}14.69 \pm \\
8.50\end{array}$ & $97.6 \%$ & $42.40 \pm 24.13^{\mathrm{b}}$ & $95.9 \%$ & $\begin{array}{l}0.36 \pm \\
0.005\end{array}$ & $0.20 \pm 0.01$ \\
\hline DMSO 10\% (NC) & $1.04 \pm 0.707$ & $\begin{array}{c}10.66 \pm \\
7.81\end{array}$ & - & $32.80 \pm 12.56$ & - & $0.11 \pm 0.01$ & $0.16 \pm 0.01$ \\
\hline $\mathrm{NaF} 20$ mg/Kg (PC) & $17.81 \pm 6.140^{\mathrm{a}}$ & $\begin{array}{c}0.104 \pm \\
0.33\end{array}$ & - & $242.60 \pm 37.47^{\mathrm{a}}$ & - & $8.10 \pm 1.00$ & $7.00 \pm 0.50$ \\
\hline
\end{tabular}

Each treatment contains three females and two males; NC: Negative Control; PC: Positive Control; MN: Micronucleus, PCE: Polychromatic erythrocyte, NCE: Normochromic erythrocyte, CTI: cytotoxic index; AU: Arbitrary units; SD: Standard deviation; Tukey's Parametric test. ${ }^{a}$ significant difference from the negative control $(p<0.05) ;{ }^{b}$ significant difference from the positive control $(p<0.05)$.

Like the results of the Micronucleus test, the data from Comet analysis of extraction of bone marrow erythrocytes in mice showed that all the doses evaluated ( $P$. aduncum $+\mathrm{NaF}$ ) were capable of reducing the NaF-induced DNA damage.

\section{Discussion}

This study aimed to determine the antioxidant capacity of the methanolic extract of P. aduncum and was performed using the most important markers, such as TBARS which measures the lipoperoxidation, meaning damage to lipid substances by free radicals; DPPH which measures specific free radicals; and FRAP which measures the antioxidant effect by reduced iron ions. The extract demonstrated that it has very high levels of these markers; therefore, it has a high antioxidant activity related to the high concentration of polyphenols and flavonoids. These markers were compared with studies from Indonesia [24], and they turned to have greater antioxidant capacity than the extracts from other studies.

The evaluation of acute oral toxicity showed a $\mathrm{LD}_{50}$ of $>2000 \mathrm{mg} / \mathrm{kg}$, which comes as no surprise because it is a solution almost purely composed of flavonoids and polyphenols, and it has been widely used by the native people by thousands of years with no apparent adverse reactions. This $\mathrm{LD}_{50}$ ranks in the 5th category of the OECD which corresponds to extremely low toxicity and has low risk of toxic reactions when orally administrated.

The Micronucleus test and the Comet assay are two of the most reliable markers for mutagenic and teratogenic activity in cells with high mitotic activity. They show chromosomic damage, and therefore genotoxicity, in this case in immature erythrocytes exposed to substances like sodium fluoride. These markers also provided information about the protector effect which some substances have on the DNA. The results show that as the concentration of the extract rises, the Micronucleus frequency and the damaged nucleotides drops. Therefore, the methanolic extract of Piper aduncum can protect DNA from damage caused by some substances. As shown by the cytotoxic index, which shows the capability of the cell to mature, more cells mature when they have higher concentration of the extract, meaning there was no DNA damage, either because of successful reparation or because there was no damage at all. These benefits can be explained because of the extract's high antioxidant activity which can offset the oxidant effect of sodium fluoride, which otherwise alters DNA by producing free radicals. Furthermore, it is known that fluoride increases caspase- 3 , caspase-8, caspase- 9 , and bax protein expression, and reduces bcl-2 protein expression in rodent liver [25]. 
In future studies, it is recommended to elucidate the mechanism of the methanol extract of P. aduncum in order to understand its antioxidant and cytoprotective effects.

\section{Conclusions}

In conclusion, the methanolic extract of Piper aduncum has a cytoprotective effect against mutagenic substances such as sodium fluoride. Also, this extract has proven to have very high antioxidant activity, a high concentration of flavonoids and polyphenols, and a very low index of acute oral toxicity, with a $\mathrm{LD}_{50}$ of $>2000 \mathrm{mg} / \mathrm{kg}$.

Studying of antimutagenic substances should be performed widely, especially with products of low toxicity and low or non-adverse reactions. Therefore, a more specific study should be performed to isolate the exact components of this extract.

Author Contributions: O.H.-C.; J.P.R.-A. and L.M.V.F.-V. designed the experiment and conducted the laboratory experiments, O.H.-C.; R.A.Y.-P.; J.A.T.-J. and C.F.-Q. wrote the original draft and writing-review and editing, L.C.-R., E.E.-R. and B.P.-O. conducted the data analysis.

Funding: This research received no external funding.

Acknowledgments: Authors thank Jorge Luis Arroyo Acevedo from the Universidad Nacional Mayor de San Marcos (Lima-Peru) for providing samples of Piper aduncum L leaves.

Conflicts of Interest: The authors declare no conflict of interest.

\section{References}

1. Herrera-Calderon, O.; Alvarado-Puray, C.; Arroyo-Acevedo, J.L.; Rojas-Armas, J.P.; Chumpitaz-Cerrate, V.; Hañari-Quispe, R.; Valenzuela-Herrera, R. Phytochemical screening, total phenolic content, antioxidant and cytotoxic activity of five peruvian plants on human tumor cell lines. Pharmacogn. Res. 2018, 10, 161-165. [CrossRef]

2. Thao, N.P.; Luyen, B.T.; Widowati, W.; Fauziah, N.; Maesaroh, M.; Herlina, T.; Manzoor, Z.; Ali, I.; Koh, Y.S.; Kim, Y.H. Anti-inflammatory flavonoid C-glycosides from Piper aduncum leaves. Planta Med. 2016, 82, 1475-1481. [CrossRef]

3. Okunade, A.L.; Hufford, C.D.; Clark, A.M.; Lentz, D. Antimicrobial properties of the constituents of Piper aduncum. Phytother. Res. 1997, 11, 142-144. [CrossRef]

4. Morandi-Ade, A.; Bergamo, D.C.B.; Kato, M.J.; Cavalheiro, A.J.; Bolzan-Vda, S.; Furlan, M. Circadian rhythm of anti-fungal prenylated chromene in leaves of Piper aduncum. Phytochem. Anal. 2005, 16, 282-286. [CrossRef]

5. Morandim, A.D.A.; Kato, M.J.; Cavalheiro, A.J.; Furlan, M. Intraspecific variability of dihydrochalcone, chromenes and benzoic acid derivatives in leaves of Piper aduncum L. (Piperaceae). Afr. J. Biotechnol. 2009, 8, 2157-2162.

6. Orjala, J.; Wright, A.D.; Behrends, H.; Folkers, G.; Sticher, O.; Rüegger, H.; Rali, T. Cytotoxic and antibacterial dihydrochalcones from Piper aduncum. J. Nat. Prod. 1994, 57, 18-26. [CrossRef]

7. Marques, A.M.; de Paiva, R.A.; da Fonseca, L.M.; Capella, M.A.; Guimarães, E.F.; Kaplan, M.A.C. Preliminary anticancer potency evaluation and phytochemical investigation of methanol extract of Piper claussenianum (Miq.) C. DC. J. Appl. Pharm. Sci. 2013, 3, 13-18.

8. Majdalawieh, A.F.; Carr, R.I. In vitro investigation of the potential immunomodulatory and anticancer activities of black pepper (Piper nigrum) and cardamom (Elettaria cardamomum). J. Med. Food. 2010, 13, 371-381. [CrossRef]

9. Orjala, J.; Erdelmeier, C.A.; Wright, A.D.; Rali, T.; Sticher, O. Five new prenylated p-hydroxybenzoic acid derivatives with antimicrobial and molluscicidal activity from Piper aduncum leaves. Planta Med. 1993, 59, 546-551. [CrossRef]

10. Song, G.; Wang, R.L.; Chen, Z.Y.; Zhang, B.; Wang, H.L.; Liu, M.L.; Gao, J.P.; Yan, X.Y. Toxic effects of sodium fluoride on cell proliferation and apoptosis of Leydig cells from young mice. J. Physiol. Biochem. 2014, 70, 761-768. [CrossRef]

11. Evariste, L.; Lagier, L.; Gonzalez, P.; Mottier, A.; Mouchet, F.; Cadarsi, S.; Lonchambon, P.; Daffe, G.; Chimowa, G.; Sarrieu, C.; et al. Thermal Reduction of Graphene Oxide Mitigates Its in vivo Genotoxicity toward Xenopus laevis Tadpoles. Nanomaterials 2019, 9, 584. [CrossRef] [PubMed] 
12. Beranek, M.; Malkova, A.; Fiala, Z.; Kremlacek, J.; Hamakova, K.; Zaloudkova, L.; Borsky, P.; Adamus, T.; Palicka, V.; Borska, L. Goeckerman Therapy of Psoriasis: Genotoxicity, Dietary Micronutrients, Homocysteine, and MTHFR Gene Polymorphisms. Int. J. Mol. Sci. 2019, 20, 1908. [CrossRef]

13. Arroyo-Acevedo, J.; Chávez-Asmat, R.J.; Anampa-Guzmán, A.; Donaires, R.; Ráez-Gonzáles, J. Protective Effect of Piper aduncum Capsule on DMBA-induced Breast Cancer in Rats. Breast Cancer. 2015, 9, 41-48. [CrossRef]

14. Arroyo-Acevedo, J.L.; Herrera-Calderon, O.; Rojas-Armas, J.P.; Chumpitaz-Cerrate, V.; Franco-Quino, C.; Hañari-Quispe, R. Chuquiraga spinosa Lessing: A Medicinal Plant for Gastric Cancer Induced By N-Methyl-N-Nitroso-Urea (NMU). Pharmacogn. J. 2018, 10, 20-24. [CrossRef]

15. Rao, A.R.; Sinha, A.; Selvan, R.S. Inhibitory action of Piper betle on the initiation of 7,12-dimethylbenz[a]anthracene-induced mammary carcinogenesis in rats. Cancer Lett. 1985, 26, 207-214. [CrossRef]

16. Brand-Williams, W.; Cuvelier, M.; Berset, C. Use of free radical method to evaluate antioxidant activity. LWT-Food Sci. Technol. 1995, 28, 25-30. [CrossRef]

17. Draper, H.H.; Hadley, M. Malondialdehyde determination as index of lipid Peroxidation. Methods Enzymol. 1990, 186, 421-431. [CrossRef] [PubMed]

18. Wolfe, K.L.; Liu, R.H. Structure-activity relationships of flavonoids in the cellular antioxidant activity assay. J. Agric. Food Chem. 2008, 56, 8404-8411. [CrossRef]

19. OECD. Guideline for Testing of Chemicals. Acute oral Toxicity-Acute Toxic Class Method, Guideline No. 423. Adopted 2001; Organization for Economic Cooperation and Development: Rome, Italy, 2001; pp. 1-14.

20. OECD. Guideline for the Testing of Chemicals Tg 474 Mammalian erythrocyte micronucelus test. In OECD Guidelines; Organization for Economic Cooperation and Development: Rome, Italy, 2014; pp. 1-16.

21. OECD. Test No. 489: In Vivo Mammalian Alkaline Comet Assay, OECD Guidelines for the Testing of Chemicals; Organization for Economic Cooperation and Development: Rome, Italy, 2014; pp. 1-21.

22. Insanu, M.; Marliani, L.; Dinilah, N.P. Comparison of antioxidant activities from four species of piper. Pharmaciana 2017, 7, 305-312. [CrossRef]

23. Ramos, M.; Ramos, D.F.; Remsberg, C.M.; Takemotoc, J.K.; Daviesc, N.M.; Yáñez, J.A. Identification of Polyphenols and Anti-Oxidant Capacity of Piper aduncum L. Curr. Bioact. Compd. 2008, 1, 18-21.

24. Sunila, E.S.; Kuttan, G. Immunomodulatory and antitumor activity of Piper longum Linn. and piperine. J. Ethnopharmacol. 2004, 90, 339-346. [CrossRef] [PubMed]

25. Yan, X.; Feng, C.; Chen, Q.; Li, W.; Wang, H.; Lv, L.; Smith, G.W.; Wang, J. Effects of sodium fluoride treatment in vitro on cell proliferation, apoptosis and caspase- 3 and caspase- 9 mRNA expression by neonatal rat osteoblasts. Arch. Toxicol. 2009, 83, 451-458. [CrossRef] [PubMed]

(C) 2019 by the authors. Licensee MDPI, Basel, Switzerland. This article is an open access article distributed under the terms and conditions of the Creative Commons Attribution (CC BY) license (http://creativecommons.org/licenses/by/4.0/). 